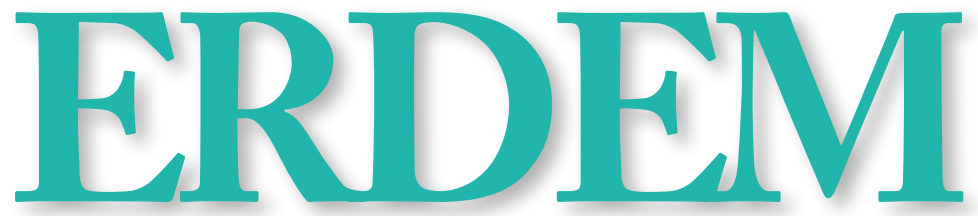

İNSAN VE TOPLUM BİLİMLERİ DERGİSİ

Münire Kevser BAŞ

Poetik Bir Metin Olarak Ebubekir Eroğlu’nun

"Yol Elçisi" Şiiri

Evşen ÇERKEŞLİ

Kurtuluş Savaşı ve Cumhuriyet İdeolojisini Edebî

Düzlemde Okumak: Dikmen Yıldızı Örneği

Hivren DEMIR ATAY

Tekerlerden Tekrarlara Gamba’da Dönüş ve Dönüşüm

Selma GÜNAYDIN

Edebî Bir Siyer Örneği Olarak Cöle İnen Nửun

Kaynakları

Mustafa GÜNDÜZ

Türk Eğitim Sisteminde Aşırı Militarist

Uygulamanın Başlaması (1926-1947)

Nagihan GÜR

Edebiyat Tarihi Yazımında Bir Kaynak Olarak

Takrizler ve Sıra Dışı İki Örnek

Osman ÖZEN - Kemalettin KUZUCU

Türk Basın Tarihinde Artin Asaduryan Matbaası ve

Matbaada Basılan Süreli Yayınlar

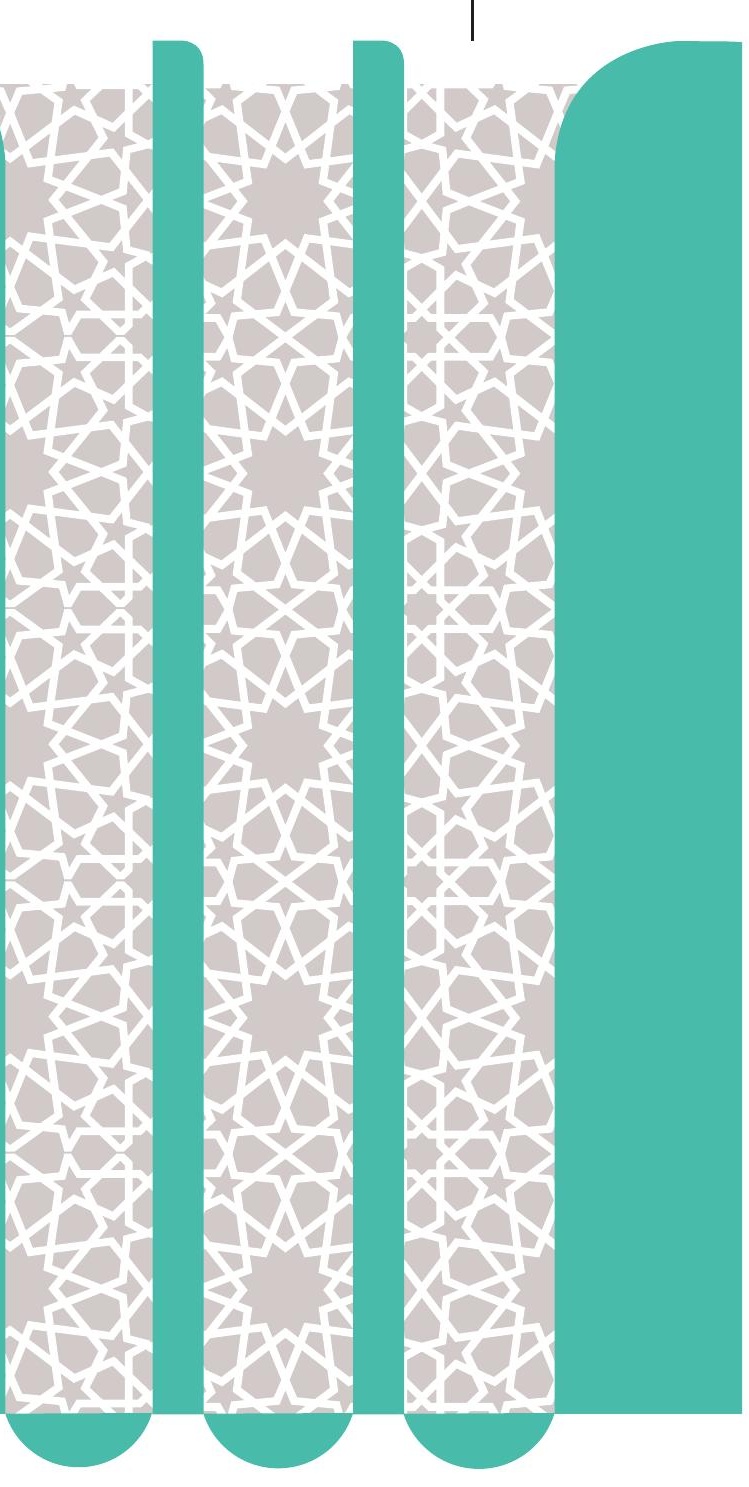




\section{ERDEM}

İNSAN VE TOPLUM BİLIMLERI DERGİSİ

JOURNAL OF HUMANITIES AND SOCIAL SCIENCES

Atatürk Kültür Merkezi tarafindan yayımlanan Erdem, insan ve toplum bilimleri alanında makalelere yer veren, hakemli bir uluslararası dergidir.

Haziran ve aralık aylarında olmak üzere yılda iki sayı çıkar.

Erdem, EBSCO, MLA ve TÜBİTAK/ULAKBİM SBVT tarafindan dizinlenmektedir.

Erdem, published by Atatürk Culture Centre, is a peer-reviewed international journal that publishes articles on humanities and social sciences.

It is published twice a year in June and December

Erdem is indexed in EBSCO, MLA and TÜBİTAK/ULAKBİM SBVT.

Görüş ve önerileriniz için editörlerimizle iletişime geçebilirsiniz.

For comments and suggestions you may contact our editors.

erdemdergisi@gmail.com 
Kültür yayıncılığın öncüsünden

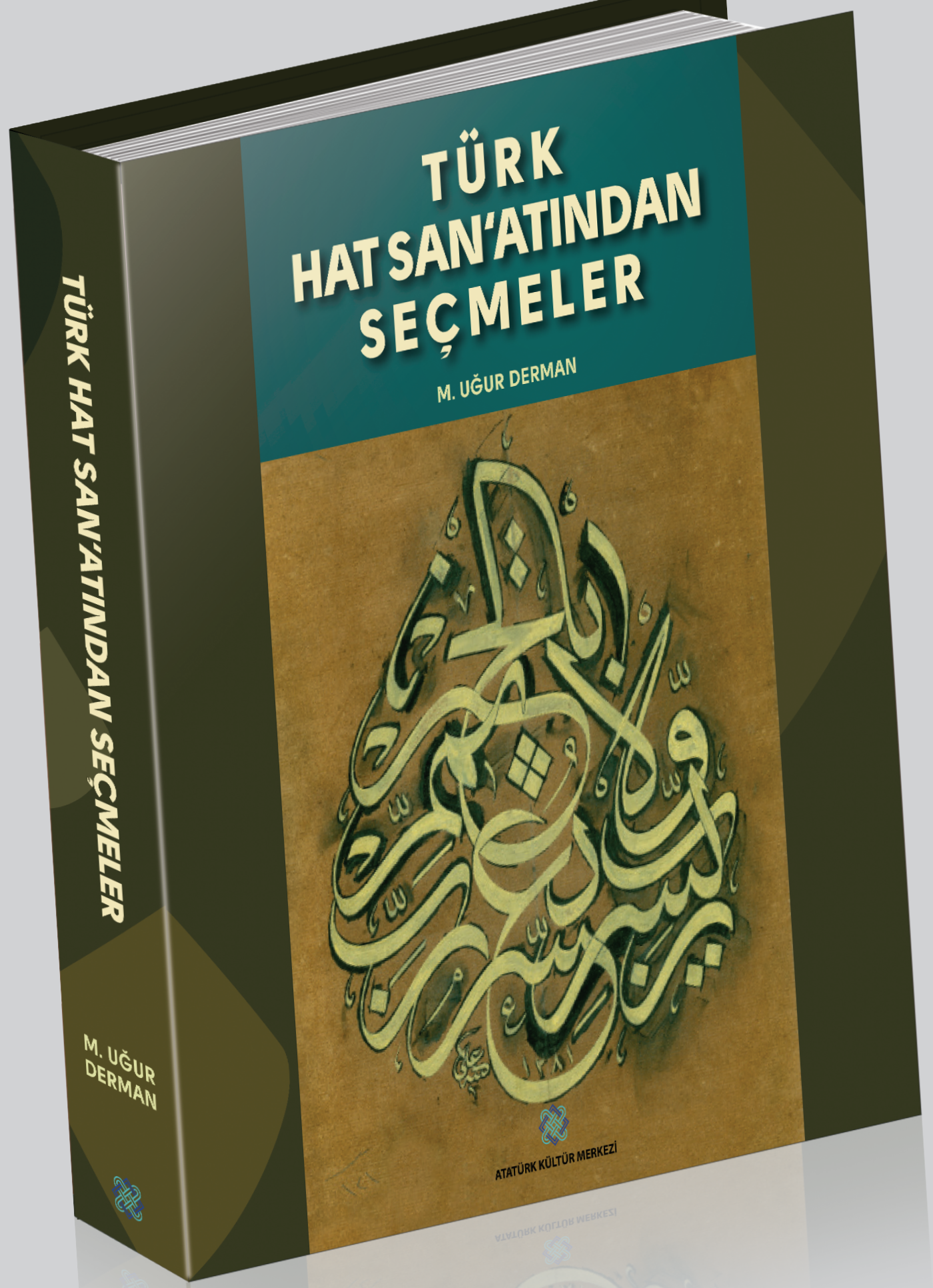




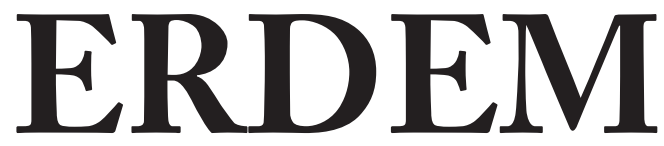

İnsan ve Toplum Bilimleri Dergisi

Journal of Humanities and Social Sciences

SAYI 71-72 • ARALIK 2016 - HAZIRAN 2017

ATATÜRK KÜLTÜR, DIL VE TARIH YÜKSEK KURUMU ATATÜRK SUPREME COUNCIL FOR CULTURE, LANGUAGE AND HISTORY

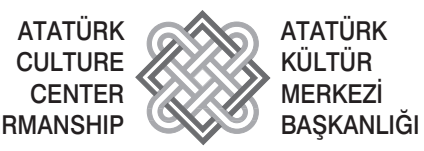




\section{ERDEM}

İnsan ve Toplum Bilimleri Dergisi

Journal of Humanities and Social Sciences

\section{DANIŞMA KURULU/ADVISORY BOARD}

Prof. Dr. Hakkı ACUN (Gazi Üniversitesi)

Prof. Dr. Hüseyin AKKAYA (Cumhuriyet Üniversitesi)

Prof. Dr. Âdem CEYHAN (Celâl Bayar Üniversitesi)

Prof. Dr. Hamza ÇAKIR (Erciyes Üniversitesi)

Prof. Dr. Mustafa ÇiçEKLER (İstanbul Medeniyet Üniversitesi)

Prof. Dr. Nurettin DEMIR (Hacettepe Üniversitesi)

Prof. Dr. Hayati DEVELI (İstanbul Üniversitesi)

Prof. Dr. Esin KÂHYA (Emekli öğretim üyesi)

Prof. Dr. Ramazan KAPLAN (Ankara Üniversitesi)

Prof. Dr. Alâattin KARACA (Muğgla Üniversitesi)

Prof. Dr. Selçuk MÜLAYIM (Marmara Üniversitesi)

Prof. Dr. Ahmet Yaşar OCAK (TOBB Üniversitesi)

Prof. Dr. Öcal OĞUZ (Gazi Üniversitesi)

Doç. Dr. Mehmet BİRGÜL (Uludağ Üniversitesi)

Doç. Dr. İdris Nebi UYSAL (Karamanoğlu Mehmetbey Üniversitesi) 


\section{ERDEM}

SAYI 71-72 • 2016-2017

Kurucu/Founder

Ord. Prof. Dr. Aydın SAYILI (1913-1993)

Sahibi/Owner

Atatürk Kültür Merkezi adına Başkan

Zeki ERASLAN

Yayın Kurulu/Editorial Board Prof. Dr. Muhammet HEKIMOĞLU

Prof. Dr. Güray KIRPIK

Doç. Dr. Bilal ÇAKICI

Uzm. Ömer ÇAKIR

Yüksek Kurum Uzm. Murat Altan ERİK

Yüksek Kurum Uzm. Yrd. Ömer GÖK

Yazı İşleri Müdürü/Managing Editor

Başkan Yardımcısı Şaban ABAK

Editörler/Editors

Yüksek Kurum Uzm. M. Altan ERİK

Uzm. Yrd. Ömer GÖK

İngilizce Özetler/English Abstracts Ayşegül ÖZDOĞAN

Yönetim Yeri/Managing Office Ziyabey Caddesi No: 19 Balgat 06520 Ankara, TÜRKIYE

Tel.: +903122843425 erdemdergisi@gmail.com www.akmb.gov.tr

GrafikTasarım/Graphic Design Grafiker Grafik-Ofset Matbaacılık

Reklamcılık San. ve Tic. Ltd. Şti Mustafa YAVUZ

Bask1/Print

Grafiker Grafik-Ofset Matbaacılık Reklamcılık San. ve Tic. Ltd. Şti. www.grafiker.com.tr

Yayın Türü/Publication Type Süreli Yayın

Yılda İki Sayı Çıkar ISSN 1010-867X

Baskı Tarihi/Print Date Haziran 2017
Değerli okurlar,

Erdem'in 71 ve 72 . sayıları ile karşınızdayız. Ülkemizde yaşanan hain darbe girişimi, tüm kamu kurumlarını derinden etkilediği gibi Kurum olarak bizim çalışmalarımızı da sekteye uğratmıştır. Bu sebeple Haziran 2016'da çıkaracağımız 71. sayıyı ancak 72. sayı ile birlikte siz değerli okuyucularımıza takdim ediyor, bundan sonra böyle gecikmelerin yaşanmamasını umuyoruz.

Sevgili okurlar, bu sayımızda edebiyat, basın ve eğitim tarihini ilgilendiren yazıların yanı sıra Selma Günaydın’ın “Edebî Bir Siyer örneği Olarak Çöle İnen Nur'un Kaynakları"nda Necip Fazıl Kısakürek; Doç. Dr. Münire Kevser Baş'ın "Poetik Bir Metin Olarak Ebubekir Eroğlu'nun 'Yol Elçisi' Şiiri”nde ise Ebubekir Eroğlu gibi kültür dünyamızın öncü isimlerinin eserleriyle ilgili inceleme yazılarını da muhtevi yedi makaleye yer verilmiştir. Kültür ve edebiyat tarihimize 1ş1k tutan birbirinden değerli bu makalelerin siz değerli okurlarımız tarafindan ilgiyle karşılanacağını ümit ediyoruz.

Dün olduğu gibi bugün de Erdem dergisi niceliği değil, niteliği önemseyen anlayışını devam ettiriyor. İki sayı birlikte çıkarmamıza rağmen bu anlayışımızdan yine taviz vermedik. Onlarca makaleden oluşan ancak okunmayan dergiler arasinda olmaktansa sayica az fakat özgün ve yetkin makaleler içeren bir dergi olmak tercihimizdir. Bu şiarla hareket ediyor ve makale seçimlerinden hakem atamalarına değin birçok aşamayı titizlikle yürütüyoruz. Bu noktada sizlerden gelecek eleştirilere de açık olduğumuzu bildirmek isteriz. Daha iyiye ve güzele yol almak için tüm yazar ve okurlarımızin desteğine talibiz.

Gelecek sayılarda buluşmak dileğiyle.

İyi okumalar,

\section{Şaban ABAK}




\section{ERDEM}

Say1 71-72 • Aralık 2016-Haziran 2017

\section{İÇINDEKILER/CONTENTS}

\section{Münire Kevser BAŞ}

Poetik Bir Metin Olarak Ebubekir Eroğlu'nun “Yol Elçisi” Şiiri

Ebubekir Eroğlu's Poem "Yol Elçisi” As a Poetic Text

\section{Evşen ÇERKEŞLI}

Kurtuluş Savaşı ve Cumhuriyet İdeolojisini Edebî

Düzlemde Okumak: Dikmen Yıldızı Örneği

The War of Independence and The Republican Ideology in

Literary Level: Dikmen Yıldizı Example

\section{Hivren DEMIR ATAY}

Tekerlerden Tekrarlara Gamba'da Dönüş ve Dönüşüm

From Bicycles to Cycles: Return and Transformation in Gamba

\section{Selma GÜNAYDIN}

Edebî Bir Siyer Örneği Olarak Çöle İnen Nư'un Kaynakları

Roots of Çöle İnen Nur As a Literary Example of Siyar

\section{Mustafa GÜNDÜZ}

Türk Eğitim Sisteminde Aşırı Militarist Uygulamanın Başlaması (1926-1947)

Starting Excessive Militarism in The Turkish Educational System (1926-1947)

\section{Nagihan GÜR}

Edebiyat Tarihi Yazımında Bir Kaynak Olarak Takrizler ve Sıra Dışı İki Örnek

Takriz Texts as a Source of Literary History Writing and Two Unusual Examples

\section{Osman ÖZEN - Kemalettin KUZUCU}

Türk Basın Tarihinde Artin Asaduryan Matbaası ve Matbaada Basılan Süreli Yayınlar ..... 117-138 Periodical Publishing Works and Artin Asaduryan Press in Turkish Press History

Yayın İlkeleri.

Editorial Principles 


\title{
Kurtuluş Savaşı ve Cumhuriyet İdeolojisini Edebî Düzlemde Okumak: Dikmen Yıldızı Örneği
}

\section{EVŞEN ÇERKEŞLi*}

\begin{abstract}
ÖZ
Bir toplumu derinden etkileyen savaşların o toplumun edebiyatında kendine yer bulması kaçınılmazdır. Aynı durum Kurtuluş Savaşı için de geçerlidir. Osmanlı Devleti'nin 1919-1923 yılları arasında Anadolu'da farklı devletlerle olan mücadelesi, ardından kurulmaya çalışılan rejimle bu yeni yönetimin ve idari kadroların yapılanma sürecindeki kendilerini meşrulaştırma ve resmî tarih oluşturma çabaları Türk edebiyatında pek çok romana, oyuna konu olmuş, hatta bunların bir kısmı doğrudan Atatürk tarafindan ısmarlama olarak yazdırılmıştır. Çünkü toplumsal kırılmaların kalıcı olması yalnızca cephede kazanılan bir savaş değildir. Hâkim ideolojiyi halkın zihninde somutlaştırıp tabana doğru nüfuz edebilmek için edebiyatın gücünden yararlanılır. Aka Gündüz, başta Dikmen Yıldızı olmak üzere pek çok eserinde resmî ideolojiye hizmet eden üslubu benimser. Genel olarak bu dönem ürünlerinde belli kadın erkek tiplerinden bahsetmek mümkündür. Erkekler korkusuz ve vatan aşkı uğruna bireysel aşkı hiçe sayan nitelikteyken kadınlar güçlerinin yettiğince onlara destek olmaya çalışan hemşirelerdir. Dikmen Yıldızindaysa bu imajlar daha da kuvvetlenir. Y1ldız; bizatihi savaşan, nişanlısının şehadetine dahi ağlamayan bir kadındır. Başka bir deyişle resmî ideoloji tarafından kadına atfedilen her türlü temsil unsuru, Yıldız'da vücut bulur. Bu çalışmada Osmanlı kötücülüğü ve cumhuriyet olumlaması altında söylevvârî bir üslupla yazılan Dikmen Yıldızı aracılığıyla ideoloji ve edebiyat ilişkisi sosyolojik eleştiri yardımıyla incelenecektir.
\end{abstract}

Anahtar sözcükler: Cumhuriyet ideolojisi, Kurtuluş Savaşı, roman, tip, sosyolojik eleştiri

Okt., Altınbaş Üniversitesi, Rektörlük/İSTANBUL

E-posta: evsen.cerkesli@kemerburgaz.edu.tr 
Roman, Türk edebiyatına bir "tür” olarak Tanzimat'la beraber girmiştir. İlk olarak Fransızcadan yapılan çeviriler görülür, ardından yerli romanlar yazılır. Bundan önceki edebiyata baktığımızda düzyazı geleneğimizin gelişmemesinden yani asıl türün "şiir" olmasından ve İslam inanışının bireyci yönde değil "ümmet kaynaşması yönünde” (Mengi 1999: 16) tavır takınmasından -çünkü roman bireyin iç dünyasını işler- düzyazının geç geliştiği görülür. Bu nedenle Tanzimat Dönemi öncesinde Türk edebiyatında hacimli olayların aktarımında kullanılan anlatı türü, mesnevidir. Çünkü "mesnevi, anlatılmas1 sayfalar tutacak uzun hikâyelerin, öğretici konuların işlendiği, (...) geniş çaplı eserler için başvurulabilecek tek nazım şeklidir” (Akün 1994: 404). Tanzimat'la beraber düzyazının yaygınlaşması neticesindeyse roman, olaya dayalı bu nevi uzun hikâyelerin anlatıldığı tür konumuna erişir.

1908'den sonra, sadece ferdi temaları işleyen, dilde Servet-i Fünun nesrinin bir devamı olan, sosyal hayat ve onun sorunları ile genellikle ilgisiz Fecr-i Ati hikâye ve romanlarının yanı başında; daha çok hayata ve sosyal meselelere yönelen, yapma dil ve üslubu bir yana bırakarak konuşma dilini ve üslubunu hâkim kılmaya çalışan yeni bir hikâye ve roman tarzının da yer almaya başladığı görülür (Akyüz 1995: 179).

Edebi eserlerin olanı anlatması gerektiği görüşünden beslenen, dönemin sosyo-ekonomik konularıyla paralellik gösteren, birçok sanatçıyı etkileyen damarlar meydana gelir. Örneğin, Balkan Savaşı'ndaki yenilginin ardından başlayan milliyetçilik akımı doğrultusunda imparatorluğun geçirdiği buhran$l_{1}$ evreler edebiyata olduğu gibi yansır. Yaşananlardan bir ders alınmasını isteyen yazarlar ise bu dönemde gözleme önem verir ve gerçekçi bir yol izlerler. Nitekim tüm bu gelişmelerin 1şı̆̆ında edebiyatın, Kurtuluş Savaşı'nın bu topraklarda bıraktığı olumlu ya da olumsuz hiçbir izi göz ardı etmesi beklenemezdi. Dolayısıyla "Milli Edebiyat, Meşrutiyet'ten sonra benimsenen İstanbul Türkçesiyle, yerli konu ve tiplerin işlenmesini (...) esas alan bir edebiyat akımı [olarak doğar]" (Okay 2009: 57).

\section{Kurtuluş Savaşı Romanı}

1919-1923 yılları arasında Anadolu'nun çeşitli yerlerinde yaşanan savaş s1rasında halk, bir yandan Osmanlı İmparatorluğu'nun bir yandan da Ankara'daki yeni hükûmetin arasında kalır. Çünkü işgal kuvvetlerinin yurttan temizlenmesini bütün halk istemekle beraber, savaş sonrasında neler olacağına, saltanatın ve imparatorun durumuna, yeni yönetim biçimine ve eskiden imparatorluğun yanında yer alanlara ne olacağına dair belirsizlikler imparatorluğa sıkı sıkıya bağlı olanlarla yeni hükümetin yeni yönetim biçimini benimseyenler arasında bir ikilik yaratıyordu. Bu durumda oluşturulmaya çalışılan düzenli orduya destek vermesi beklenen halk, düşmanla savaşmak ve sultana 
karşı gelmek arasında kalır. Ankara Hükûmeti'nin Anadolu'nun çeşitli yerlerinde insanları mücadeleye dâhil etmek için gösterdiği çaba; küçük yerlerde, kasabalarda eşraf ve din adamları üzerinden yürütülür. Savaş bölgesine gizli gizli silah yollanması, gönderilenlerin de korunup gerekli kişilere dağıtılması hep halkın katılımıyla gerçekleştirilir. Ancak insanların bahsedilen ikilemlerinden kurtulup mücadeleye katılmaları hiç kolay değildir. Tüm bu zorluklardan sonra yeni kurulan cumhuriyetin kendi söylemini, ideolojisini oluşturma ve yayma aşamasına gelinir. Zaman zaman hükûmet eliyle de yazdırılan, oluşturulmaya çalışlan yeni resmî tarihi destekleyen, yeni nesle bunu öğretmeye, hatta ezberletmeye gayret eden cumhuriyetin resmî bakış açısını yansıtan kitaplar, insanların psikolojisine yönelmek yerine olaylara ve olayların akışı esnasında Mustafa Kemal'e düşen en önemli göreve odaklanır. Buradaki tarih anlayışına göre, Osmanlı'ya gelindiğinde bir kesintiyle karşılaş1lır. Tarihin bu altı yüz yıllık dönemi göz ardı edilerek, küçümsenerek yapılan anlı şanlı işler sadece Kurtuluş Savaşı'na ve onun mimarlarına aitmiş gibi çizilir. Çünkü "Osmanlı tarihinin 'hanedan tarihi' olmasına karşılık Gazi Mustafa Kemal tezinin ana ögesi 'millet'tir. Milleti alır, onu okur, onu araştırır, onu anlatır, hayat ve istikbaline ait düsturları ancak onun tarihinden çıkarır" (Kurdakul 1994: 22). Bunun yanında cumhuriyetin ihtiyacı olan yeni insan tipi de bu anlatılarda dikte edilir. Cumhuriyetin ink1laplarına sahip çıkan, gönül meselelerini devlet meselelerinden önce tutmayan insanlardır bunlar.

Kurtuluş Savaşı'nın ve bu insan tipinin sıkça yer aldığı romanların yazımı cumhuriyetin kurulduğu ilk yıllardan günümüze kadar devam etmiştir. Kurtuluş Savaşı'nı konu edinen romanların ayrı tür mü olduğu yoksa bunların "roman" türünün bir alt türü mü olduğu da başka bir tartışma konusudur. Toplumu derinden etkilemiş, insanlar üzerinde fazlasıyla iz bırakmış, edebiyatın çokça ilgilendiği bir konu olan Kurtuluş Savaşı, "roman” üst türünün alt türü sayılabilecek niteliktedir. Alastair Fowler Kinds of Literature kitabının "Transformations of Genres" bölümünde bununla ilgili: "Mevcut dağarc1ğa her bir yeni başlik eklendiğinde "tür" değişir. Genelde de var olan türle beraber yeni bir başlı̆̆ın gelişiminden söz etmek mümkündür" der (Duff 2000: 233). Ayrıca bu damarda verilen çok sayıda eserin yanında türün kendi üslubunun, dilinin, ideolojisinin- Kemalizm-, karakteristiğinin olması da onu bir "alt tür" yapmaya yetmektedir. Bu romanlarda, düşman Yunan'dır ya da Rum, Ermeni azınlıklarla iş birliği yapan savaş zengini Türklerdir. Erkekler cephede savaşan, ülküsünü her şeyin üstünde tutan, güçlü, genç kişilerdir; kadınlarsa zeki, alımlı, çevresindeki erkekleri etkilemeyi başaran, bu etki altında onlara mücadele azmi veren, aktif mücadelede yer almasa bile genellikle hemşirelik, hastabakıcılık yaparak ya da cepheye mermi taşıyarak 
cepheden desteğini eksik etmeyen, cinsî albenisi törpülenmiş kişilerdir. İşlenen kadın karakterlerin sınıflandırılması Bahriye Çeri'nin Türk Romanında Kadın 1923-1938 incelemesinin "Kurtuluş Savaşı Yıllarında Kadın” başlıklı bölümünde yapılarak 1919-1923 yılları arasında yazılan romanlarda ele alınan kadın karakterlerin, yaşanan toplumsal ve tarihi hareketliliğe paralel olarak Türk edebiyatının daha önceki kadın tiplerinden büyük değişiklikler gösterdikleri belirtilir:

Millî Mücadele içinde Türk kadınlarının etkinlikleri çok önemlidir. $\mathrm{Bu}$ dönemdeki kadınları, içinde bulundukları durum ve etkinlikleri bakımından birkaç grupta toplamak mümkündür.

1. İ̇sgal bölgesindeki karşılaştıkları zor durumlar nedeniyle erkekleri göreve çağıran kadınlar

2. Eline silah alarak bizzat savaşa katılanlar veya cephe gerisinde hizmet verenler (Yaraliya bakanlar, askere yiyecek-giyecek temin edenler)

3. Geniş kitleyi uyandırmak için dernek ve basın etkinliklerine katılanlar. Bunların en ünlüleri, başta Halide Edip olmak üzere Nakiye Elgün, Müfide Ferit Tek'tir.

4. Etkinliklere moda diye bakanlar ve bu yüzden katılanlar, İstanbul sosyete hanımları (1996: 21-22).

Yaratılan bu aydın, elitist karakterler vasıtasıla Kemalist politika, olumlanan ve olumlanmayan örneklerin hikâyeleriyle başta yetiştirilmek istenen yeni nesle olmak üzere toplumun her kademesine ulaştırılır. "Kurtuluş/kuruluş romanları" roman üst türü içerisinde kendilerine bu özellikleriyle bir yol açmayı başarmıştır. Cumhuriyet dönemi idarecileri kurmaya çabaladıkları tarih ve rejim anlayışının kitlelere benimsetilmesi, bunların içselleştirilmesi için kültüre ve edebiyata ihtiyaç duymuşlardır; oluşturulan "kuruluş/kurtuluş" savaşı kanonu, "ulus-devlet projesinin ve yaratılmak istenen millî kimliğin yansımalarıyla" insanların kendilerini birleşmiş bir milletin yurttaşları olarak görmesini sağlar (Balabanlilar 2003: 14).

Edebîlikleriyle değil de daha çok belli bir amaca hizmet etmeleriyle değer kazanan, yoğun olarak cumhuriyetin ilk on beş yılında yazılan bu tarz romanların yanında, daha ileri tarihlerde yazılan ve savaş yıllarında yaşayanların çeşitli dramlarını, ruhsal gelgitlerini anlatan romanlar da vardır.

Yazardan yazara, dönemden döneme ele alınan konunun işleniş biçimi farklilıklar gösterse de Kurtuluş Savaşı temasıyla yazılan ve roman türüne dâhil edilen eserlerin göz ardı edilemeyeceği muhakkaktır. Ancak yazılan her yeni eserle birlikte bu konunun işlendiği "tür" yeni bir yön kazanır, çünkü "türe eklenen her yeni eser, türe yeni bir şey eklediği gibi türde birtakım sapmalara 
da neden olur” (2000: 234). İşte bu doğrultuda yaklaşık yüz y1llık külliyata bakıldığında Mürşit Balabanlılar'ın hazırladı̆̆ı Türk Romanında Kurtuluş Savaşı kitabının giriş bölümünde Ömer Türkeş’in değindiği gibi bu romanlar üç bölümde toplanabilir. Bunlar; daha çok kendi içimizdeki düşmanın yani azınlıklarla iş birliği yapanların hainliğinin vurgulandığı I. dönem (1920-1950), cumhuriyet öncesi ve sonrası resmî tarihe dışardan bakabilen II. dönem (1950-1980) ve emperyalizmle onun işbirlikçilerine direnenleri anlatan daha milliyetçi çizgideki III. dönem (1950-1980) romanlarıdır (2003: 15-23).

Dikmen Yıldızı romanı yukarıda anlatılan sinıflandırmalar kapsamında değerlendirildiğinde kadın karakter(ler) özelinde ikinci alt başlıkta ifade edildiği gibi "eline silah alarak bizzat savaşa katılanlar veya cephe gerisinde hizmet verenler” sınıfına dâhil olduğu söylenebilir. Ayrıca Dikmen Yıldızinın Türkeş’in sınıflandırmasının da ilk grubuna dâhil edilebileceğini belirtmek gerekir.

\section{Dikmen Yildizi'nın Konusu}

Romanın bahsi geçen özellikleri doğrultusunda çalışmanın başlığında iddia edildiği üzere cumhuriyet ideolojisinin açık bir şekilde propagandasını yürüttüğünü sosyolojik eleştirinin yardımıyla ele almak, çalışmanın bundan sonraki başat meselesi olacaktır. Bu amaçla öncelikle romanın geniş özetini vermekte fayda var:

Dikmen Yıldızı; İzmirli bir baba ve Denizlili bir annenin kızı olan, güzeller güzeli, cesur, vatanını korumak için canını ortaya koymaktan çekinmeyen Yıldız’ın hikâyesidir. Yıldız, savaş pilotu olan Murat’la gönül bağı kurar. Ancak bu öyle bir aşktır ki vatan aşkı ve selametiyle paralel olarak ilerler. I. ve II. İnönü Savaşları, Kütahya-Eskişehir Savaşı, Sakarya Meydan Savaşı, Dumlupınar Savaşı ve son olarak İzmir'in 9 Eylül'de düşman işgalinden kurtarılması ile Yıldız ve Murat, tıpkı geleceği için önünde engel kalmayan Türkiye gibi aşklarını yaşama firsatı bulur. Zaten romanın başından beri İzmir'in kurtuluşu ile özdeşleştirilen Yıldız'nn mutluluğu için hiçbir mani kalmaz. Olay akışı anlamında bu şekilde özetlenebilecek olan Dikmen Yıldızinın kurgusu ve yan olayları ile ana düşünce ve yardımcı düşüncelerine de bakmak bu çalışmanın önermesi gereği romanın cumhuriyet ideolojisinin sözcülüğünü nasıl yaptığını göstermede yardımcı olacaktır.

Roman; Yıldız’n bir Ankara sabahında kucağında bebeğiyle savcıya gidererek annesini, babasını, aile dostları Nedim'i ve yardımcıları Süleyman'ı nişanlısı Murat'ı boğup ikiz bebeklerinden erkek olanı öldürmekle suçladığı 
sahneyle açılır. Kademe kademe Yıldız'n kendini vatan savunmasına nasıl adadığ1 anlatılırken bir yandan yurdun içinde bulunduğu vahim durumu sonlandıracak olay olarak İzmir'in kurtuluşu sunulur ki Yıldız'ın da bizatihi İzmir'in kızı olarak anıldığı düşünülürse Yıldız’ın vücudunda tüm Türk kadınının özellikleri somut hâle gelir. Yıldız'ın on altı kişilik kadın ve çocuk kafilesine önderlik yapmasından başlayarak onun cesaretine atıfta bulunulur. $\mathrm{Bu}$ arada Nedim'in hareketlerinden kendisine ilgisi olduğu zannına kapilan Yıldız birtakım kuruntular yaşamaya başlar ki daha sonra bunlar hem kendisinin hem de ailesinin yanlış anlamalarla çeşitli üzüntüler yaşamasına sebep olacaktır.

Öte yandan Yıldız'nn güzelliği ve cesareti ile herkesçe tanınan, saygı duyulan hâle gelmesiyle beraber Murat da başarısı ve aklıyla Türk subayları arasında sivrilir. Kurtuluş Savaşı çeşitli cephelerde ilerlerken Anadolu insanı güzellemeleri de Dikmen Yıldızının alamet-i farikalarındandır. Eğitimsiz ya da kir pas içinde olsalar dahi Anadolu insanının saflığı, merhameti ve gözü karalığ1 övülür. Onların yüksek sezgi ve kavrama kabiliyeti üzerinde durulur. Bu iman ve inançla art arda cephelerde başarılar elde edilirken kurulacak Yeni Türkiye'nin nasıl bir zemine oturtulacağ şeceği de romanın ana izleklerindendir. Olaylar yaşanırken ailesinin Murat'la evlilik işlerini ertelemesinde bir şer arayan Yıldız, onların bu izdivacı ülkenin kurtuluşu sonrasına bırakma isteklerine -daha doğrusu İzmir'in düşmandan temizlenmesinin ertesine birakma taleplerine - karşın Murat'la hemen bir evlilik düşler. Çünkü eğer sonraya kalırsa ailesinin herhangi bir bahanenin arkasına sığınarak Murat'la ayrılmasına vesile olarak kendisini Nedim'le evlendireceğine inanır ve bu vahamet neticesinde Yıldız'la Murat ailelerine inat birlikte olur. Bu birliktelikten doğan ikizlerinden birine ve Murat'a ailesinin kötülük yaptığı fikri daha önce belirtildiği gibi romanın başlangıcından itibaren ele alınır. Ama hurafelere inanmış Yıldız's, Kastamonu'da -Ecevit Geçidi'nde- vatan savunması için karşılaştığı Anadolu insanının sıcaklığı ve olaylar karşısındaki yıkılmazlığ deyim yerindeyse sağaltır. Onun kapıldığ kuruntulardan kurtulup gerçeklerle yüzleşmesi, vatanın düşmandan ve yaratılıp inanılan yabancı hâkimiyetinden sıyrılmasıyla eş zamanlıdır. Yıldız kucağındaki bebeğin aslında başından beri bir taş bebek olduğunu nihayet kabul ederek ailesine güttüğü kinden de vazgeçer. Aka Gündüz ün yalnızca Yıldız ve Murat ilişkisi özelinde -çünkü romanın genelinde gerçekçi anlatımın tercih edildiği, doğrudan tarihi verilere ve karakterlere yer verildiği hatta anlatıcı yazarın araya girerek hem okura bilgi verdiği hem de Dikmen Yıldızının yazılışı hakkında konuştuğu görülmekle beraber- alegorik bir anlatımı benimseyip Yıldız aracılığıyla Türkiye'nin uyanışını özdeşleştirdiği söylenebilir. 
Nitekim sonda Murat'ın yaşadığı ortaya çıkar, iki sevgili kavuşur. Kısacası İzmir' in düşmandan temizlenmesi İzmir'in kızının da sevgilisinin de miladı olur.

\section{Dikmen Yıldızı'nda Cumhuriyet İdeolojisinin İzini Sosyolojik Eleştiri Aracılığıyla Sürmek}

Romanda sembolik bir anlatımın değil doğrudan anlatımın tercih edilmesinin esas sebebi, toplum mühendisliği hususunda edebiyatın önemli ve kritik rolünün farkında olan cumhuriyet kadrolarının ve yazar Aka Gündüz'ün öğreticilikten uzaklaşmak istememeleridir. Başka bir deyişle okurun zihninde yanlış anlamalara mahal vermemek adına ve halkı eğitmek gayretinin bir yansıması olarak romandaki her ayrıntı açıkça ifade edilir, herhangi bir muğlak nokta bırakılmamaya gayret edilir. Çünkü hedef kitlenin verilmek istenen mesajı yanlışsı ve tam olarak alması amaçlanır. Dolayısıyla sosyolojik eleştirinin Dikmen Yıldızinın incelenmesindeki etkisi bir kat daha önem kazanmaktadır. Çünkü ilk olarak 1927 yılında basılan bu romanı devrin sosyal şartlarından bağımsız düşünmek eksik bir değerlendirme olacaktır. "Sosyolojik eleştiri edebiyatın kendi başına var olmadığı, toplum içinde doğduğu ve toplumun bir ifadesi olduğu ilkesinden hareket eder" (Moran 2016: 83). "Sanatın toplumu yansıttığı" (2016: 85) görüşünden yola çıkarak Dikmen Yıldızinın cumhuriyetin kuruluş merhalelerini ve inkılaplarla yeni toplum düzeninin oluşturulmaya çalı̧ıldığ 1 erken dönemini, devrin idari kadrolarının hâkim bakış açısını yansıtarak aydınlattığı söylenebilir. "Sosyolojik eleştiri büyük ölçüde betimleyicidir" (2016: 86). Nitekim Dikmen Yıldızı da dönemin kadın-erkek rolleri, toplumsal hayatı, zihniyeti hakkında adeta sözcüklerle bir tasvir yapar ve bu tasvirin yoruma açık bir tarafi yoktur. Yani her okuyanın aynı şeyi anlaması; romanın yanlış, eksik ya da farklı yorumlanmaması için yazar edebiyatı amaç olmaktan çıkarıp araç hâline getirir. Dolayısıyla bu roman, Türk edebiyatında edebî söylemiyle yer bulamasa da didaktik tavrıyla ve yazıldığı dönem göz önüne alındığında amacına doğrudan hizmet eder.

Öncelikle yazarın yerli yersiz bilgi verme gayretinden bahsetmek gerekir ki bu tercihin halkın yetişmiş kişilerce eğitilmesi gerektiği fikrine dayandığg iddia edilebilir. Türk tarihinden bazı anekdotlar ${ }^{1}$ ile Türk ve dünya tarihinden, edebiyatından, mitolojisinden ${ }^{2}$ kimi kahramanlardan söz edilir. Romanı oku-

1 “Milli Mücadelede istilaya uğramış yerlerin Ankara'da bulunan halkı birer yurt kurmuşlardı.” şeklinde bir tarihi bilgi doğrudan paylaşılır (Gündüz 2012: 84).

2 Yıldız, Alangoya adlı Moğol Destanı'nın kutsal sayılan kadın kahramanından üstün tutulur (Gündüz 2012: 243). Ayrıca Venüs ve Apollon'dan bahsedilerek güzellik timsali olarak anılacak biri varsa onun 
yarak bilgilenmesi hedeflenen alıcı kitle dikkate alındığında, o kimselerin çok az bir kısmının bu türlü bilgilere sahip olduğu hatta hiçbirinin bunları bilmediği söylenebilir. Bu üslup, yazarın bilgisini paylaşma ve cahil halkı eğitme politikasının uzantısıdır.

"Milli Mücadele mazlum bir milletin kaynayan benliğinden taşmıştır"(2012: 86) denerek Kurtuluş Savaşı halkın eliyle yürütülen bir değişimin başlang1c1 olarak kurgulanır. Halktan taşan bu türlü duygu ve arzuları durdurmanın imkânı olmadığından dönüşüm kaçınılmaz hâle gelmiş, yeni bir devletin kurulması kaçınılmaz olmuştur, denmek istenir.

Osmanlı eleştirisi yapılırken aynı zamanda kadınlara sosyal hayatta uygulanan kısıtlayıcı ve gerici yasaklara da karşı çıkılır. Yıldız'ın kadınlara yasak olduğu için kahvede oturamayışı (2012: 87) ve aşırı batı hayranı arkadaş1 Nazlı aracılığıyla kadını yalnızca süsten ibaret gören zihniyet eleştirilir (2012: 251). Çünkü yeni rejimin her ikisinden de farklı ve makul bir kadın önerisi vardır: Güzelliğinin farkında olarak bunu kullanmayan ama erkeklerden de kaçmayıp kamusal alanda gerektiğinde onlarla omuz omza durabilen bir kadın. Zaten Yıldız da kendisine prenses yakıştırması yapan arkadaşı Nazlı ile gerçekleştirdiği sohbette şahsı için: "Çirkinliği kabul etmem. Fakat mutlaka güzelliğimden bahsedeceksen Nazl, bana prenses kadar diyeceğine bir İzmir kızı kadar güzelleşmişsin demelisin” der (2012: 250).

Savunulan bu yeni kadın tipinin kimi özellikleri ise hem onun zayıf yönünü oluşturur hem de aslında cumhuriyet kadrolarının her ne kadar eskiden farklı olduklarını iddia etseler de söz konusu kadın olunca sınırlı bir yenilik önerisinin ötesine geçemediklerini gösterir. Mehmet Tekin'in ifadesiyle burada "tip, kendi dı̧̧ında bir şeyi temsil eden roman kişisidir” (Tekin 2001: 110). Yıldız da cumhuriyetin olumlanan kadın tipini temsilen romanda şöyle nitelenir: “Şu inkılap devrinin örnek kızı! Yarınki ideal kadın, ideal anne!” (2012: 187). İdeal neslin yetiştiricisi olarak "Anadolu'nun bütün dört örgülü, saz benizli, hasretli kızların[ın] her birisinden tüten ocaklar, kapılarından fişkıran çocuklar meydana gelecek" (2012: 215) denerek yine kadınlara yeni yönetimce biçilen görev ve sorumluluklar belirtilir. Çünkü "temel sağlık politikalarında başarılı olmak, sağlıklı bir nesil yetiştirmek ve nüfus yoğunluğunu hızla artırmak, Kemalist siyasi elitler açısından kısa zamanda bir prestij meselesi ve meşruiyet kaynağı hâline dönüşmüştür” (Akın 2004: 91-92).

da Yıldız olması gerektiği söylenir (Gündüz 2012: 258). Nitekim bu noktada Yıldız’’n isminin sembolik anlamı manidardır. Yazar, başkahramanına yol gösterici olarak Yıldız ismini vermekle ona yüklediği misyonu pekiştirir. 
Romanda Yıldız'ın savcıya Murat'la güya evlenmişler gibi günlük rutinlerini anlattığı bir konuşmasında, Murat yazıhanesine, "ben dikişime" (2012: 77) diyerek dışa karşı sert, net bir tavır sergiler. Ancak söz konusu aile, aşk olduğunda sonuna kadar klasik bir Türk kadını gibi davrandığını ispatlar. Yıldız toplumsal alanda erkek gibi olmasına, savaşmasına hatta kendisine emanet edilen on altı kişinin bakımını savaş şartlarında bile layıkıyla yerine getirmesine rağmen kendi yuvasının dişi kuşudur, bu konuda dı̧̧arıdakinin aksine çok kırılgan bir tavrı vardır; yapıcı bir rol üstlenir. Habermas'ın belirlediği gibi yaşamda iki ayrı alan vardır: "Toplumsal-kamusal alan" ve "özel alan”. Kadının özel alanı olan evinden çıkıp da toplumsal alanda varlık gösterebilmesi çok kolay değildir. "Çünkü ataerkil ideolojiler kadınların varoluşunu mahremiyet, sessizlik, doğallık, gizem gibi kavramlarla tanımlayarak (...) kamusalın karşıtı olarak kurgular" (Irzık ve Parla 2004: 7). Murat, bir erkekten beklenecek şekilde hem kamusal alanda hem de eşiyle ilişkisini yaşadığı özel alanda rüştünü ispat etmişken bir kadın kamusal alanda Yıldız kadar güçlü, korkusuz olsa da özel alanda korunmaya muhtaç, kolay incinen bir yapıdadır ve domestik işlerin sorumluluğunu üstlenir. Kısacası dışarıda erkek, içeride hâlâ kadın olan bir Yıldız söz konusudur.

Atatürk'ün “en büyüğümüz” olarak nitelendirildiği romanda, Murat'ın babas1-Beybaba- doğrudan cumhuriyetin savunuculuğunu üstlenir; eski yönetim anlayışını şu sözlerle eleştirir:

Niçin ve ne hakla hükümdar? Niçin ve ne hakla baskı? Milletim, ülkem, devletim diye milleti, ülkeyi, devleti kahve ocağı gibi kullanmak isteyenlere lanet olsun! Ben pırasa, sen terlik, o saksı, öteki av köpeği değildir ki, bir sahibimiz olsun. Ben bir şahsın veya hanedanın teb'ası! Hayır Yıldız! Ben kendimin tebasıyım. Kendi saltanatımın hükümdarıyım. Hükümdarlığın bir tohumu vardır, adına zorbalık derler. Tarihleri baştan başa tetkik et, göreceksin ki, en büyük imparator, cihanın rahminden zorba olarak dünyaya firlamıştır.

Bir tarihte İstanbul'da bulundum. Beni Taşkışlayya hapsettiler. Sebebini sordum. Dediler ki; sen burada olduğun hâlde iki seneden beri selamlı̆̆a gelmemişsin, sebebi nedir?

Mert ve doğru bir asker sıfatıyla;

-Çünkü dedim, padişahın ve padişahlğ̆ın aleyhindeyim.

Beni oradan attılar. Fizan’a sürdüler. Oradan durmadım, kaçtım. Meşrutiyet, rütbemi geri verdi; senelerden sonra bir gün İstanbul, padişahlar, imparatorlar ve krallar çorbasına döndü. Başına taç geçiren İstanbul'a geldi, bir 'ala ala hey!' başladı. Kerataların hepsi de zulme uğramış ve mahkûm bir millete kuşbakışı bakıyorlardı. Sarayda merasim vardı. Gitmedim. Yerim boş kaldı. Sebebini sordular: 
-Çünkü dedim, padişahın ve padişahlığın aleyhindeyim.

Bak maskaralara! Beni tekrar ordudan atmak için divanı harbe verdiler. Dedim ki: 'Bunu ben söyledim; bir elinizi Türk taribine, bir elinizi kalbinize koyarak bükmünüzü siz veriniz.'

Bir dakika sonra suçsuzluk kararımı aldılar (2012: 138-139).

Beybaba, romandaki en belirgin cumhuriyet savunucusu tipidir. Öyle ki k1sıtlı sayfada yer alan Beybaba, herhangi bir karakter gelişimi göstermeksizin yalnızca belli bir ideolojinin sözcülüğüne soyunur. Bu yönüyle tam manasıyla bir tiptir. Tip; doğduğu koşulların tekdüzeliğini kıran yani romanın başından sonuna büyük bir düşünsel, ruhsal değişim geçiren, içine doğduğu koşulları kabullenmek yerine bunlarla çatışmayı seçen, eleştirel karakterin tam tersidir. Yani tip, romanın başlangıcında nasıl kurgulanıp sunulmuşsa sonunda da bu çerçeveye uygun davranır. Nitekim Beybaba örneğinde de görüldüğü gibi kurgulanma amacının dışında tek laf etmediği gibi konuştukları da yalnızca bu amaç çerçevesinde gelişir. Yukarıdaki pasajdan da rahatlıkla anlaşılacağı gibi imparatorluk karşıtlığının temsilcisi olarak iyi ve kötü ikileminde kötülerin konuşmanın sonunda hatalarını anlamasıyla Beybaba -ve aslında onunla beraber tüm cumhuriyet taraftarları- kendini aklar. Çünkü Osmanlı, işgalcilerle beraber romanın diğer “ötekisi” olarak sunulur.

Romanda Osmanlı'daki hâkim sanat anlayışı "hâlâ resme çizgi, müziğe ilahi diyenler” (2012: 192-193) sözleriyle eleştirilirken eğitim sisteminin kadın ve erkeği ayrı konumlandırmasına dinen münasip olmaz bahanesiyle yaklaşılmasına karşı çıkılır. Cumhuriyetle beraber bu alanlarda yapılacak yeniliklere bir anlamda göndermede bulunulur. Bizatihi Yıldız da piyano çalar.

Tüm sosyal mecralarda yapılacak düzeltmelerin işaret fişekliğini yapan Dikmen Yıldızı, inkılapların yanı sıra elitist tavra dair de birtakım unsurlar barındırır. Halktaki gücü, Anadolu'daki bakir, saf, eğitime muhtaç ama her şeyden öte güçlü halkı yetiştirmekle istenen Türkiye'ye ulaş1labileceği pek çok defa tekrar edilir. Kendini halka yakın hatta onunla bir konumlandıran Yildız'ın nezdinde cumhuriyet ideolojisinin köye ve köylüye bakışı çok net biçimde sezilir. Ancak tüm iyi niyetli övgülere rağmen romanın satır aralarında yeni rejimin Anadolu halkını "basit, mektepsiz bir dağ çocuğu” (2012: 157) olarak görmekten kurtulamadığı Yıldız’ın şu sözlerinden anlaşılır:

Al sana etten, candan, duygudan ve Türk'ten bir alay bebek! dedi. Bak ne güzel yumurcaklar, içlerinde temizi, sümüklüsü, çarıklısı, yarım entarilisi hepsi hepsi vardi.

Bir koca havlu sabunladım... Ahmet'le beraber hepsinin yüzlerini, ellerini, bacaklarını bir iyice temizledim. 
Ah, aziz ve hami dost!

Ah ne güzel, ne şirin, ne sahiden bebek oldular (2012: 184)!

Yıldız'ın bakış açısından aktarılan bu diyaloglar bir nevi Anadolu güzellemesi olmakla birlikte Anadolu insanından hareketle gerçekleştirilecek toplum mühendisliği idealinde, oradaki halkın mutlaka istendik şekle sokulması, doğal görünümlerinden kurtulması başat beklentidir. Ayrıca tıpkı Yıldız'ın yaptığ1 gibi bebeklere yani genç nesle ve dimağlara yönelmek, cumhuriyet ideolojisini öğretip yaymanın en makul ve kolay yoludur. Buna karşın yaklaşmaya çalışılan Anadolu ile cumhuriyet arasındaki farkın tamamen kapandığını söylemek imkânsızdır. Bu hem yukarıda da ifade edildiği gibi üsttenci ve romantik yaklaşımın sonucudur hem de Anadolu'yu gelenek, görenek, tarihsel doku, coğrafî şartlar ve beğeni ölçütleri dâhilinde tam manasıyla anlamamış olmaktan kaynaklanır. Daha açık söylemek gerekirse Anadolu'nun kendi bağrından kopup onunla özdeşleşen ögeler cumhuriyet kadrolarında pek yankı bulmaz. Örneğin müzik zevki ele alınacak olursa Yıldız bir kere olsun saz ya da bağlama çalmak istediğini söylemez veyahut Anadolu'nun en büyük kıymetlerinden olan türkülerden hiç bahsedilmezken aynı Yıldız'n piyano çalışına birkaç yerde değinilir. Dolayısıyla aslında Yıldız'ın da temennisi, Anadolu'dakilere bir zaman sonra -yani gerekli eğitim süreci tamamlandığında- piyano çaldırmaktır yorumuna varılabilir. Buradan bakıldığında halkla mesafesini her zaman korumak niyetinde olan ilk dönem cumhuriyet aydının bir prototipi çizilir.

\section{Sonuç}

Çekirdeğini Kurtuluş Savaşı'nın ve cumhuriyetin kuruluşunun oluşturduğu romanlar, yaşanan çağla hep doğrudan ilişkili olmuştur. Dikmen Yıldızı romanı yazıldığı dönem ve şartlar çerçevesinde incelenmeye muhtaç tezli bir romandır. Aka Gündüz'ün ideolojik koşullanması tezin ele alınışında doğrudan etkilidir. Bu yönüyle roman, edebî manada büyük bir değer taşımasa da bir dönemin zihniyetini aydınlatma hususunda pek çok malzeme barındırır. Yeni Türkiye için adeta çoban yıldızı olan Yıldız' in fikrî kurtuluşu düşmandan kurtuluşunun da öncülü olur. Dikmen Yıldızı bir bakıma somut düşman Yunanlılara ve kültürel düşman Fransızlara karşı Anadolu halkıyla topyekûn yürütülen, Kastamonu'dan İzmir'e uzanan bir destan olan Kurtuluş Savaşı'nın kadınlara adanmış romanıdır. Anadolu halkının fiziksel kuvvetliliğinin, dayanıklılı̆̆ının yanında olaylar karşısındaki soğukkanlılığına, dirayetli duruşuna da güzelleme yapılır. Cumhuriyetin ve değerlerinin inşası sırasında ilkeleri, hedefleri ve inkılapları görünür kılmak amacıyla ele alınan bu romanda yüzünü Batı'ya dönen, bağımsız Türkiye'nin kadın-erkek bir arada yükselece- 
ğine atıfta bulunulur. Söylemin kalıcı hâle gelip gelecek nesillere ulaşması için yazının gücünden sonuna kadar yararlanılır. Özetle Dikmen Yıldızinda edebiyat bir silah gibi kullanılarak edebiyatın tarih ve sosyoloji bilimleriyle kurduğu güçlü bağdan destek alınıp cumhuriyet ideolojisinin yansımasına yer verilir.

\section{Kaynaklar}

Akın, Yiğit (2004). "Gürbüz ve Yavuz Evlatlar" Erken Cumburiyet'te Beden Terbiyesi ve Spor, İstanbul: İletişim Yayınları.

Akün, Ömer Faruk (1994). "Divan Edebiyatı", Türkiye Diyanet Vakfi İslam Ansiklopedisi, C.9, s.389-427.

Akyüz, Kenan (1995). Modern Türk Edebiyatını Ana Gizgileri, İstanbul: İnkilap Kitabevi.

Balabanlılar, Mürşit (2003). Türk Romanında Kurtuluş Savaşı, İstanbul: Türkiye İş Bankası Kültür Yayınları.

Çeri, Bahriye (1996). Türk Romanında Kadın, 1923-1938 Dönemi, İstanbul: Simurg Yayınları.

Duff, David (2000). Modern Genre Theory, Singapore: Longman.

Gündüz, Aka (2012). Dikmen Yıldızı, İstanbul: Toker Yayınları.

Irzık, Sibel ve Parla, Jale (2004). Kadınlar Dile Düşünce: Edebiyat ve Toplumsal Cinsiyet, İstanbul: İletişim Yayınları.

Kurdakul, Şükran (1994). Çağdaş Türk Edebiyatı 3, Cumburiyet Dönemi 1, Şiir, İstanbul: Evrensel Basım Yayın.

Mengi, Mine (1999). Eski Türk Edebiyatı Taribi, Ankara: Akçağ Yayınları.

Moran, Berna (2016). Edebiyat Kuramları ve Eleştiri, İstanbul: İletişim Yayinlar1.

Okay, Orhan (2009). Batılılaşma Devri Türk Edebiyatı, İstanbul: Dergâh Yayınlar1.

Tekin, Mehmet (2001). Roman Sanatı, İstanbul: Ötüken Neşriyat. 


\section{ABSTRACT \\ The War of Independence and The Republican Ideology in Literary Level: Dikmen Yıldızı Example}

It is inevitable that the wars which affect a society deeply take place in the literature of that society. The same is true for the War of Independence. The struggle of the Ottoman State with the different states in Anatolia between 1919-1923, then the effort of the new regime and its staff to legitimize themselves and establish official history in the process of structuring new administrations and administrative staff have been the subjects of many novels and plays in Turkish literature. Even some of them are printed directly by Atatürk as custom-made. Because persistence of social breakdown is not a war that can be won only in the front. The power of literature is exploited to embody the dominant ideology in the minds of the people and to penetrate the base. Aka Gündüz, in many literary products, especially Dikmen Yildizı, adopts to the style that serves to official ideology. In general there are certain female and male stereotypes in the literary products of this period. While men are fearless and noble for individual love for the sake of homeland love, women try to support them as long as they can affort as sisters. These images become stronger in Dikmen Yildız. Yildiz who takes a position in the war and who does not even cry for the martyrdom of his fiance. In other words, every fact of representation attributed to the woman by the official ideology is found in Yildiz. In this work, ideology and literature relation will be examined with the help of sociological criticism through Dikmen Yıldızı written in a narrative style under the Ottoman malaism and Republican affirmation.

Keywords: Republican ideology, War of Independence, novel, stereotype, sociological critique 
